\title{
EFEKTIVITAS MODEL PROBLEM BASED LEARNING DALAM MEREDUKSI DISPARITAS GENDER PADA CAPAIAN PEMBELAJARAN SAINS
}

\author{
Pusfarini \\ SMPN 23 Bandar Lampung, Jl. Jendral Sudirman No 76 Rawa Laut, Enggal, Bandar Lampung, Indonesia \\ e-mail: agus.pusfa@gmail.com
}

Diterima: 12 Januari 2017. Disetujui: 11 April 2017. Dipublikasikan: 29 April 2017

\begin{abstract}
Abstrak: Bias gender atau gender gap sering menjadi permasalahan dalam pencapaian kompetensi siswa pada pembelajaran sains. Meminimalisasi gender gap di kelas-kelas sains telah menjadi fokus penelitian para pakar pendidikan sains dunia, termasuk di Indonesia. Tujuan penelitian ini adalah untuk mendeskripsikan dampak pembelajaran sains yang berorientasi pada model Problem Based Learning (PBL) dalam mereduksi gender gap dalam capaian pembelajaran sains. Metode penelitian kuantitatif kuasi eksperimen dengan disain non-equivalent pre-post group digunakan dalam penelitian ini. Hasil analisis data mengungkapkan bahwa implementasi model PBL dengan melibatkan sejumlah perangkat pembelajaran yang relevan dapat mereduksi gender gap pada pembelajaran sains, yang ditunjukkan oleh hasil uji- $t$ terhadap $N$-gain kedua kelompok putra dan putri siswa SMP dalam topik Indera Pendengaran dan Sistem Sonar pada Makhluk Hidup, menunjukkan hasil belajar yang tidak berbeda secara signifikans $(p>0,05)$.
\end{abstract}

Kata Kunci: gender gap, PBL, hasil belajar, pembelajaran sains

\section{THE EFFECTIVENESS OF THE PROBLEM-BASED LEARNING MODEL IN REDUCING GENDER DISPARITY IN SCIENCE LEARNING ACHIEVEMENTS}

\begin{abstract}
Gender gap is one of the problems in achieving science learning objectives. To minimize the gender gap in science learning has become the focus of research in world science education experts, including in Indonesia. This study aims to describe the impact of science-based learning on Problem Based Learning (PBL) model in reducing the gender gap in learning achievement of science. Quantitative quasiexperimental research methods with non-equivalent pre-post group designs are used in this study. The results of the analysis indicate that applying the PBL model by involving a number of relevant learning tools can reduce the gender gap in science learning, it is shown by the t-test results on the N-gain of both groups of male and female in the topic of Sound and Sonar Systems in Living Beings. It showed the learning outcomes which do not differ significantly $(p>0.05)$.
\end{abstract}

() 2017 Pendidikan Fisika FTK UIN Raden Intan Lampung

Keywords: gender gap, learning outcomes, PBL, science learning.

\section{PENDAHULUAN}

Beberapa hasil studi menunjukkan bahwa, mutu pendidikan Indonesia masih menyisakan banyak pekerjaan rumah, terutama pada aspek mutu pendidikan. Seperti diungkap oleh laporan tentang Human Development Index (HDI) yang menunjukkan bahwa Indonesia pada tahun 2010 menempati posisi 108 dari
169, tahun 2011 berada pada ranking 124 dari 187, dan tahun 2012 memperoleh posisi 121 dari 186 (Malik, 2013). Hal tersebut menunjukkan bahwa secara signifikan kualitas pendidikan Indonesia berada dalam rentang yang sangat besar dari skor rerata internasional. Tidak terkecuali kualitas pendidikan sains, hingga kini di Indonesia pembelajaran 
sains diajarkan lebih cenderung berorientasi pada bagaimana membantu siswa meningkatkan pengetahuan kognitif, namun tidak untuk melibatkan siswa belajar bagaimana cara mengaplikasikan konsep-konsep ilmiah dalam kehidupan nyata di luar sekolah (Koedinger, Corbett, \& Perfetti, 2012).

Pernyataan ini juga senada dengan yang dikemukakan oleh Suartika, Arnyana, \& Setiawan (2013), bahwa dalam proses pembelajaran sains di sekolah-sekolah diketahui guru belum menerapkan upaya-upaya pemberdayaan kemampuan berpikir ilmiah dan mengaktifkan siswa untuk bekerja secara ilmiah. Padahal pembelajaran sains yang menitikberatkan pada keterampilan proses akan turut membentuk kreativitas ilmiah siswa dalam belajar sains yang pada akhirnya akan meningkatkan capaian pembelajaran siswa dalam sains (Aktamis \& Ergin, 2008).

Salah satu model pembelajaran yang berpotensi akan mendongkrak kemampuan berpikir siswa secara aktif dalam proses kreativitas kognitif adalah Problem Based Learning (PBL). PBL dianggap cukup konsisten dengan teori pembelajaran konstruktivis yang banyak digunakan sebagai dasar bagi program pendidikan guru (Brooks \& Brooks, 1999; Delisle, 1997; Fosnot, 2005).

Mengajar dari perspektif konstruktivis, menurut Brooks \& Brooks (1999) adalah berarti bahwa kita perlu bertanya satu pertanyaan besar. Pembelajaran konstruktivistik adalah pembelajaran aktif dan dimulai dengan memunculkan dan mengakui apa yang telah diketahui para peserta dan percaya tentang tugasnya (Fosnot, 2005).

Sebuah aspek penting dari PBL adalah bagaimana mendesain masalah yang sebenarnya sehingga termotivasi untuk dipecahkan (Hung, Jonassen, \& Liu, 2008). Pembelajaran dimulai dengan penyajian permasalahan yang solusinya dapat dielaborasi melalui penggalian dan penggunaan pengetahuan yang relevan. Selain itu juga PBL bertujuan meningkatkan kemampuan siswa bekerja dalam tim, meningkatkan kemampuan mereka yang terkoordinasi untuk mengakses informasi dan mengkonstruknya menjadi pengetahuan yang lebih komplit. Prinsip-prinsipnya PBL antara lain, yaitu: pengajuan masalah nyata yang konstekstual (otentik), berpusat pada peserta didik (student-centered), guru menemati posisi sebagai fasilitator, kolaborasi antar peserta didik, berorientasi pada prinsipprinsip konstruktivisme dengan memberikan kesempatan yang seluasluasnya kepada peserta didik untuk secara aktif memperoleh pengetahuannya sendiri. Salah satu kendala terkait dengan penerapan prinsip-prinsip PBL di kelas adalah motivasi dan kinerja belajar siswa dengan melibatkan potensi belajar yang beragam, terutama yang bersumber pada faktor gender. Gender adalah seperangkat karakteristik membedakan antara laki-laki dan perempuan, khususnya dalam kasus potensi belajar anak laki-laki dan perempuan. Perbedaan jenis kelamin, prestasi, dan kemampuan atau keterampilan siswa tetap menjadi sumber keprihatinan mutu dan akses pendidikan. Oleh karena itu sebagian ilmuwan berusaha untuk menjembatani celah besar tentang keterwakilan perempuan di tingkat tertinggi sains dan engineering (Asante, 2010).

Bastable (2008:194) menyatakan bahwa dalam menanggapi masalah, siswa laki-laki memilih memiliki rasa ingin tahu dan ketertarikan yang jauh lebih dominan. Bahkan dalam variasi pemecahan masalahnya pun siswa lakilaki memiliki point skor yang lebih besar $(O E C D, 2013)$. Dalam penelitiannya terhadap perbedaan umur dan gender, D'Zurilla, Maydeu-Olivares, dan Kant (1998) mengemukakan bahwa perbedaan yang menonjol antara laki-laki dan perempuan terletak pada arah pengenalan 
masalahnya. Laki-laki lebih positif dan dikenal lebih cepat dan tanggap dalam mengenali masalah ketika mulai memasuki masa dewasa dibandingkan dengan perempuan. Berdasarkan penelitiannya, sejak masa kanak-kanak laki-laki memang lebih mudah dalam mengenali masalah, hanya saja kepedulian laki-laki berkontribusi pada proses menyelesaikan masalah tersebut sering ditemukan kurangnya antusiasme siswa laki-laki dalam belajar dikelas dan terlihat bermalas-malasan serta kurang partisipatif dalam menyelesaikan masalah. Sedangkan pada siswa perempuan, antusiasme dalam belajar dan berusaha menyelesaikan masalah yang diberikanoleh guru terlihat lebih tinggi meskipun kurang tanggap dalam mengenali masalah tersebut. Salah satu aspek yang dapat membantu proses tersebut berjalan dengan baik adalah ketersediaan bahan ajar sangat menentukan adaptasi gender terhadap capaian pembelajaran siswa.

PBL, sebagai model pembelajaran inovatif dalam implementasinya membutuhkan bahan ajar yang relevan, seperti misalnya Lembar Kerja Peserta Didik (LKPD). Bahan ajar yang digunakan guru-guru sains, seperti LKPD, juga sangat mempengaruhi capaian pembelajaran secara signifikans, terutama membantu dalam melakukan aktivitas proses sains berupa handsonactivity (Abdurrahman, 2016).

Dalam pembelajaran sains, peserta didik mestinya dibimbing oleh guru untuk aktif menemukan sendiri orientasi pemahaman dan penguasaan materi pembelajaran melalui aktivitas berpikir. Kegiatan memecahkan masalah menjadi ciri pembelajaran IPA yang menumbuhkan secara progresif keterampilan berpikir siswa secara kreatif. Pemilihan, pengembangan, dan pengemasan materi pembelajaran seharusnya berorientasi pada bagaimana upaya pencapaian penguasaan materi pembelajaran tersebut secara komprehensif melalui penyediaan pengalaman belajar siswa yang berupa aktivitas-aktivitas yang berpusat pada siswa (Collette dan Chiappetta,1994).

Hasil studi intensif tentang tentang persamaan dan perbedaan gender dalam konteks keberhasilan dalam pencapaian pembelajaran telah dimulai pada tahun 1970-an, yang secara umum menyimpulkan bahwa siswa perempuan lebih unggul pada keterampilan verbal dibandingkan dengn siswa laki-laki (Maccoby dan Jacklin, 1974). Namun Halpern dan LaMay (2000) mengungkapkan bahwa kemampuan verbal umum, aritmatika, penalaran abstrak, visualisasi ruangan, atau rentang daya ingat antara pria dan wanita hampir tidak terdapat perbedaan yang menyolok.

Disamping itu perempuan lebih menunjukkan keterlibatan secara aktif pada materi akademis, memeperhatikan pelajaran di kelas, memfokuskan lebih banyak upaya yang bersifat akademis, dan partisipasi dalam proses pembelajaran di kelas daripada siswa laki-laki. Selanjutnya Halpern dan LaMay (2000) secara umum mengemukakan bahwa dalam hal intelegensi, banyak penelitian yang belum berhasil mengungkapkan secara konsisten apakah terdapat perbedaan yang kontras antara intelegensi anak laki-laki dan perempuan.

Faktor gender saat ini masih merupakan kajian yang menarik dalam penelitian dan pembelajaran sains. Oleh karena itu aspek gender kerap menjadi pembahasan utama berbagai program riset dan upaya peningkatan mutu dan proses pembelajaran sains. Pertimbangan ini muncul karena respon, sikap, motivasi, dan interaksi siswa laki- laki dan perempuan dalam pembelajaran sains memunculkan performa yang berbeda (Bursal, 2013). Hal ini juga ditunjukkan oleh hasil Assesment global baik Trends in International Mathematics and Science Study (TIMSS) dan Programme for 
Internasional Student Assessment (PISA), yang menunjukkan perbedaan performa yang signifikans antara siswa laki- laki dan perempuan (OECD, 2012).

Telah banyak dilaksanakan penelitian tentang faktor gender dalam proses pembelajaran sains, yaitu: Penelitian PISA dari OECD dan Unesco Institut for Statistics yang fokus utamanya mengukur kompetensi sains siswa diakhir usia wajib belajar untuk mengetahui kesiapan siswa menghadapi tantangan masyarakatberpengetahuan (knowledge society) dewasa ini (OECD, 2012). Penelitian ini berfokus pada efektivitas implementasi PBL dengan melibatkan bahan ajar LKPD yang relevan bagi sintaks PBL untuk mengurangi disparitas gender siswa SMP. Beberapa penelitian sejenis tentang efektivitas PBL telah banyak dilakukan namun hanya berfokus pada peningkatan penguasaaan konsep sains (Fosnot, 2005; Chin \& Chia, 2006; Suartika, Arnyana, \& Setiawan, 2013).

\section{METODE PENELITIAN}

Penelitian ini menggunakan metode kuasi eksprimen dengan desain kuantitatif non-eqivalent pre-post group design (Cresswel, 2013). Penelitian ini difokuskan pada pengamatan efek gender sebagai modalitas belajar siswa.

Data penguasaan konsep sains topik Indera Pendengaran dan Sistem Sonar pada makhluk Hidup diperoleh dengan instrumen tes menggunakan Inventori Penguasaan Konsep Bunyi dan Sistem Sonar (IPKBSS) Sebanyak 66 siswa terlibat dalam penelitian ini, dengan rincian 28 orang kelas laki-laki (kelompok putra) dan 38 orang di kelas perempuan (kelompok putri).

Tabel 1., di bawah ini menyajikan demografi sampel penelitian. Instrumen lain yang digunakan dalam penelitian ini adalah lembar observasi keterlaksanaan pembelajaran PBL untuk memastikan bahwa PBL berjalan sesuai dengan Rencana Program Pembajaran (RPP), dan LKPD berbasis PBL untuk mengarahkan dan memfokuskan pengalaman belajar sains pada topik Bunyi dan Sistem Sonar.

Tabel 1. Demografi sampel penelitian dan perlakuan

\begin{tabular}{llll}
\hline Kelompok & Perlakuan asesmen & $\begin{array}{l}\text { Frekuensi } \\
\text { pertemuan/minggu }\end{array}$ & Jumlah Siswa (N) \\
\hline Putra & $\begin{array}{l}\text { Pembelajaran model PBL } \\
\text { menggunakan LKPD } \\
\text { Pembelajaran model PBL }\end{array}$ & $2 \mathrm{x}$ & 28 \\
Putri & menggunakan LKPD & 38 \\
\hline
\end{tabular}

Selanjutnya data penelitian dianalisis secara deskriptif analitik dan inferensial dengan menggunakan bantuan SPSS IBM 21.

\section{HASIL DAN PEMBAHASAN}

Berdasarkan hasil pre-test dan posttest pada intrumen formatif IPKBSS, di bawah ini adalah deskripsi hasil capaian belajar baik kelompok putra maupun putri (lihat Tabel 1).

Tabel 1. Data deskriptif penguasaan konsep siswa

\begin{tabular}{ccllllll}
\hline \multirow{2}{*}{ No } & Kelompok & \multicolumn{2}{c}{ Pre Test } & \multicolumn{3}{c}{ Post Test } & \multicolumn{2}{c}{ Ngain } \\
\cline { 3 - 7 } & & Rerata & SD & Rerata & SD & Rerata & SD \\
\hline 1 & Kelas Putra & 36,36 & 5,38 & 71,99 & 8,09 & 0,55 & 0,14 \\
2 & Kelas Putri & 38,03 & 6,56 & 74,18 & 4,85 & 0,58 & 0,10 \\
\hline
\end{tabular}


Tabel 2. Uji-t N-Gain penguasaan konsep siswa

\begin{tabular}{|c|c|c|c|c|c|}
\hline \multicolumn{2}{|l|}{ Grup } & \multirow{3}{*}{$\begin{array}{l}T_{\text {hitung }} \\
-1,021\end{array}$} & \multirow{3}{*}{$\begin{array}{l}\mathrm{T}_{\text {tabel }} \\
1,669\end{array}$} & \multirow{3}{*}{$\begin{array}{l}\text { Sig. } \\
(2-\text { tailed }) \\
0,311\end{array}$} & \multirow{2}{*}{$\begin{array}{l}\text { Kesimpulan } \\
\text { Tidak terdapat perbedaan } \\
\text { peningkatan penguasaan }\end{array}$} \\
\hline N-Gain & $\begin{array}{l}\text { Putra }=0.53 \\
(\mathrm{~N}=28)\end{array}$ & & & & \\
\hline & $\begin{array}{l}\text { Putri=0,58 } \\
(\mathrm{N}=38)\end{array}$ & & & & $\begin{array}{l}\text { konsep kedua kelompok } \\
\text { secara signifikan }\end{array}$ \\
\hline
\end{tabular}

Tabel 2, menunjukkan bahwa, pembelajaran topik konsep bunyi dan sistem sonar pada makhluk hidup dengan menerapkan LKPD berbasis PBL yang mengakomodasi gender telah berhasil meningkatkan kinerja belajar siswa yang ditunjukkan oleh adanya peningkatan penguasaan konsep sains siswa. Peningkatan capaian pembelajaran ini salah satunya ditumbuhkan melalui motivasi guru agar siswa memunculkan berbagai ide-ide baru yang orisinil pada penyelesaian masalah yang ditunjukan saat bekerja dalam kelompok. Sehingga siswa mampu memberikan pandanganpandangan yang beragam atas informasi yang diberikan dalam LKPD setelah munculnya konflik kognitif atas masalah yang diberikan sehingga siswa lebih kreatif melakukan probem solving. Pernyataan tersebut didukung oleh Marzano dkk. (1988) yang menyatakan bahwa berpikir kreatif siswa bisa ditumbuhkan oleh guru di dalam kelas diantaranya melalui: (1) diskusi secara aktif topik pelajaran yang kontropersi, (2) mengajukan permasalahan yang menumbuhkan konflik kognitif dalam memori siswa, (4) menugaskan siswa menemukan ide pandangan yang bervariasi dan orisinil terhadap suatu masalah dan mencari alternatif solusinya secara kreatif.

Selain itu, dalam sintaks PBL yang diterapkan di kelas eskperimen siswa diharuskan mempresentasikan produk yang dihasilkan dan digunakan siswa dalam menyelasaikan masalah. Dalam penelitian ini sebagian besar produk yang dihasilkan siswa adalah berbentuk poster. Poster ini dibuat dalam bentuk laporan pengamatan atau sejumlah argumentasi siswa dalam menyelesaikan masalah. Karya siswa ini terlihat sangat orisinil dengan argumentasi yang dihasilkan berdasarkan hasil diskusi dan pencarian informasi baru dari sumber belajar yang tersedia, baik buku siswa maupun bahan ajar online melalui gadget atau smartphone.

Aktivitas ini diprediksi turut menunjang kinerja berpikir kreatif siswa. Sebagaimana yang dikemukakan oleh Marzano dkk (2008) yang menyatakan bahwa aktivitas seperti: (1) menugaskan siswa menulis artikel untuk diterbitkan dalam suatu jurnal (poster), (2) menganalisis artikel dari koran atau media lain (internet) untuk menemukan gagasan-gagasan baru, dan (3) memberikan bacaan yang berbeda dengan tradisi siswa untuk diperdebatkan atau didiskusikan, maka akan meningkatkan kemampuan berpikir kreatif siswa dalam melakukan problem solving, sehingga secara umum siswa mengalami peningkatan secara baik dalam penguasaan konsep-konsep sains, terutama pada topik bunyi dan sistem sonar. Gambar 1. Di bawah ini menunjukkan salah satu poster yang dikreasi oleh siswa. 


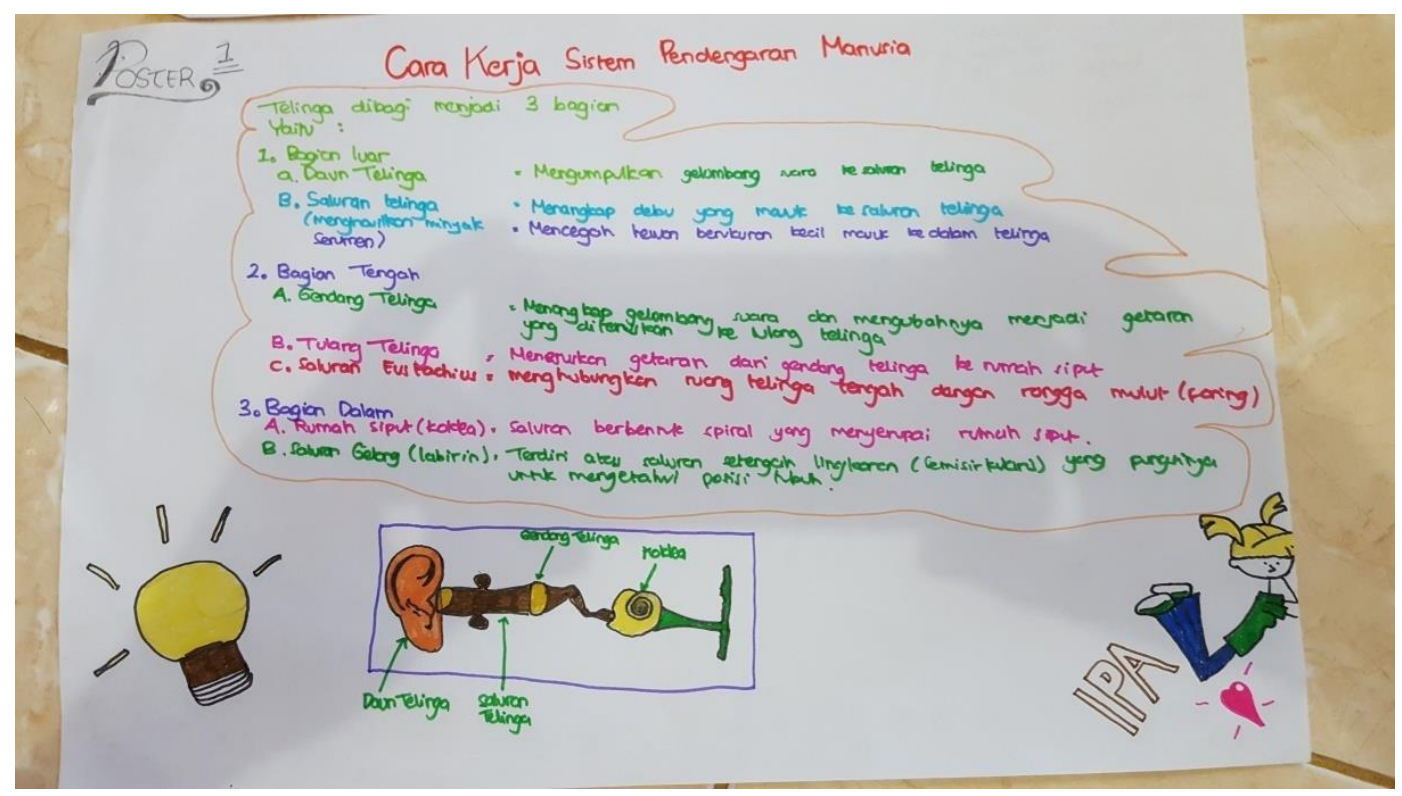

Gambar 1. Salah satu contoh poster karya siswa yang dipresentasikan

Dalam uraian di atas, tampak betapa pentingnya penerapan strategi-strategi pembelajaran inovatif yang mampu mendorong dan memicu kecakapan berpikir baik bagi siswa laki-laki maupun siswa perempuan. Kurikulum sains nasional saat ini mengisyarakan bahwa guru harus menerapkan dan mengembangkan strategi pembelajaran yang beraliran filosofi konstruktivisme. Dengan kata lain pembelajaran sains harus mampu memberikan pengalaman belajar yang nyata kepada siswa bagaimana mengkonstruk pengetahunnya sendiri melalui keterlibatannya secara aktif daam proses pembelajaran.

Dalam penelitian ini menunjukkan bahwa LKPD yang dirancang dan diterapkan dalam model PBL, yang dimulai dengan perumusan masalah riil kehidupan yang bersifat ill-structured, berhasil meningkatkan penguasaan konsep sains siswa. Perumusan masalah yang bersifat ill-structured, terbuka, dan bersifat ambigu sangat efektif melatih kemampuan berpikir siswa (Chin \& Chia, 2006; Forgaty, 1997; Jones, 1996). LKPD berbasis PBL yang dikembangkan dalam penelitian ini telah mampu membangkitkan minat siswa, nyata, dan sesuai untuk membangun kemampuan intelektual berdasarkan potensi yang dimiliki siswa, termasuk potensi gender.

Hasil menarik lainnya dari penelitian ini adalah capaian skor N-Gain penguasaan konsep sains kelompok siswa putra dan siswa putri tidak berbeda secara signifikan. Ini menunjukkan bahwa pembelajaran menggunakan LKPD berbasis model PBL mampu mengakomodasi potensi belajar gender. Temuan ini sesuai dengan pendapat Abdurrahman (2015) yang menyatakan bahwa pada inovasi pembelajaran, termasuk di dalamnya daya dukung bahan ajar, termasuk LKPD, harus dapat mengakomodasi potensi gender dan mengurangi disparitas gender. Disparitas gender selama ini masih merupakan pekerjaan rumah pada pendidikan sains. Beberapa temuan sebelumnya menunjukkan bahwa minat siswa perempuan terhadap sains jauh lebih rendah dibandingkan dengan siswa lakilaki, sehingga berdampak pada capaian pembelajaran sains, terutama pada aktivitas laboratorium (hands-on activity). Dalam kelas sains yang cenderung lebih menonjolkan aktivitas laboratorium dimana para siswa harus 
partisipasi aktif, maka nilai tes anak perempuan meningkat naik secara drastis (Santrock, 2009). Sedangkan perempuan memperoleh nilai lebih tinggi dalam bahasa verbal, termasuk penilaian membaca dan menulis, serta dalam tugastugas yang meminta perhatian dan perencanaan yang lebih rinci (Linn dan Hyde dalam Santrock, 2009; Warrick dan Naglieri dalam Slavin, 2008). Oleh karena itu proses pembelajaran dengan perangkat pembelajaran PBL yang didesain memiliki beragam representasi yang mengembangkan potensi belajar siswa, berpotensi menjadi pendongkrak capaian pembelajaran sains baik bagi siswa laki-laki maupun perempuan.

\section{SIMPULAN}

Pentingnya mendesain pembelajaran yang mengakomodasi potensi gender berdampak pada pemilihan dan penerapan model pembelajaran inovatif yang mampu menstimulasi aktivitas fisik dan kognitif siswa, sehingga mereka terlibat secara aktif dalam proses pembelajaran sains. Keterlibatan secara aktif siswa dalam pembelajaran sains tergantung pada iklim pelibatan secara emosi terutama terkait dengan kinerja kognitif gender.

PBL yang disertai dengan sejumlah perangkat pembelajaran yang kontennya menyediakan sejumlah fakta, konsep, asas, dan hukum-hukum sains yang disajikan secara beragam dan menimbulkan stimulus positif dalam sistem memori siswa laki-laki dan perempuan secara masif, akan mampu mereduksi disparitas atau gender gap dalam capaian pembelajaran sains. Hasil penelitian ini terbatas pada efektivitas LKPD yang berbasis PBL dalam mengakomodasi potensi belajar gender. Peluang bagi pengembangan bahan ajar atau media ajar lainnya yang berorientasi pada suatu model pembelajaran inovatif sangat terbuka untuk dipertimbangkan oleh para guru atau peneliti lainnya untuk mengoptimalkan potensi belajar siswa laki-laki dan perempuan secara optimal.

\section{DAFTAR PUSTAKA}

Abdurrahman, A. (2016). Pemanfaatan Science In Box dalam Pembelajaran Berbasis Inkuiri di SMP untuk Meningkatkan Penguasaan Konsep Fluida Statis. Jurnal Ilmiah Pendidikan Fisika Al-Biruni, 5(2), 205-212.

Abdurrahman. (2015). Guru Sains Sebagai Inovator: Merancang pembelajara sains inovatif berbasis riset. Yogyakarta: Media Akademi.

Aktamis, H., \& Ergin, O. (2008). The Effect on Scientific Process Skills Education on Students' Scientific Creativity, Science Attitudes and Academic Achievements. AsiaPacific Forum on Science Learning and Teaching, 9 (1).

Andriani, R. A. (2015). Perbedaan Sikap Kolaboratif Siswa Berdasarkan Gender Dalam Pembelajaran Fisika Dengan Model Collaborative Learning Di Kelas X Madrasah Aliyah Al-Ihsan Boarding School Kampar. Jurnal Online Mahasiswa (Jom) Bidang Keguruan Dan Ilmu Pendidikan, 2(2), 1-15.

Arnyana, I. B. P. (2006). Pengaruh Penerapan Strategi Pembelajaran Inovatif pada Pelajaran Biologi terhadap Kemampuan Berpikir Kreatif Siswa SMA. Jurnal Pendidikan dan Pengajaran IKIP Negeri Singaraja, 3 (6).

Asante, K. O. (2010). Sex differences in mathematics performance among seniorhigh students in Ghana.Gender and Behaviour, 8(2), 3279-3289.

Bastable, S. B. (2008). Nurse as educator. Boston: Jones \& Bartlett Publishers. 
Brooks, J.G. \& Brooks, M.G. (1999). In search of understanding: The case for constructivist classrooms. Alexandria, VA: Association for Supervision and Curriculum Development. http://asimov.coehs.uwosh.edu/ c ramer/casestudy1/Concepts/Const ructivist.html [27/01/2010].

Bursal, M. (2013). Longitudinal investigation of elementary students' science academic achievement in $4-8^{\text {th }}$ grades: Grade level and gender differences. Educational Sciences: Theory \& Practice, 13(2), 1151-1156.

Chin \& Chia. (2006). Problem-Based Learning: Using Ill-Structured Biology Project Work. Science Education. 90: 44-67

Collette, A. T., \& Chiappetta, E. C. (1994). Science instruction in the middle and science school. Columbas USA: Merrill, 47.

Creswell. J. W. (2013). Research design: Qualitative, and mixed methods approaches. Sage publications.

Delisle, R. (1997). How to Use ProblemBased Learning in the Classroom. Virginia: Association for Supervision and Curriculum Development.

D'Zurilla, J., Maydeu-Olivares, A., and Kant, G.L. (1998). Age and Gender Differences in Social Problem-Solving Ability. Journal Personality and Individual Differences, 25(2), 241-252

Fogarty, R. (1997). Problem Based Learning and Other Curricular Models for Multiple Intelligences Classroom. New York: IRI/Skylight Training and Publishing, Inc.

Fosnot, C. T. (2005). Constructivism revisited: Implications and reflections. The Constructivist, 16(1) 1-17.
Halpern, D. F., \& LaMay, M. L. (2000). The smarter sex: A critical review of sex differences in intelligence. Educational Psychology Review, 12(2) 229-246.

Hung, W., Jonassen, D. H., \& Liu, R. (2008). Problem-based learning. In J. M. Spector, J. G. Van Merriënboer, M. D., Merrill, \& M. Driscoll (Eds.), Handbook of research on educational communications and technology (3rd ed., pp. 485-506). Mahwah, NJ: Erlbaum.

Hyde, J. S., and Linn, M. C. (1988). Gender difference in verbal ability. A meta analysis. Psychological Bulletin, 104, 5369.

Koedinger, K. R., Corbett, A. T., \& Perfetti, C. (2012). The Knowledge Learning Instruction framework: Bridging the science practice chasm to enhance robust student learning. Cognitive Science, 36(5) 757-798.

Maccoby, E. E., \& Jacklin, C. (1974). The psychology of sex differences. Stanford, CA: Stanford University Press.

Malik, K. (2013). Human development report 2013. The rise of the South: Human progress in a diverse world.

Marzano, R. J., Brandt, R. S., Hughes, C. S., Jones, B. F, Presseisen, B. Z., Rankin, S. C., \& Suhor, C. (1988). Dimensions of thinking: a framework for curriculum and instruction. Alexandria, VA: Association for Supervision and Curriculum Development.

OECD. (2012).Closing the Gender Gap: Act Now, OECD Publishing. http://dx.doi.org/10.1787/978926 4179370-en

OECD. (2013). PISA 2015 Collaborative Problem Solving Framework. OECD Publishing. 
Santrock, J. W. (2009). Psikologi Pendidikan Edisi 3 Buku 1. Jakarta: Salemba Humanika.

Slavin, R.E. (2008). Educational Psychology: Theory and Practice. Terjemahan Marianto Samosir. Jakarta: PT Indeks.

Suartika, K., Arnyana, I. B., \& Setiawan, G. A. (2013). Pengaruh Model Pembelajaran Kooperatif Tipe Group Investigation (GI)
Terhadap Pemahaman Konsep Biologi dan Keterampilan Berpikir Kreatif SiswaSMA. Jurnal Pendidikan IPA, 3(1)

Warrick, P. D., \& Naglieri, J. A. (1993). Gender Difference in planning, attention, simultaneous, and successive (PASS) cognitive procceses. Journal of Educational Psychology, 85 (4), 693-701. 